\title{
Constitutional legitimacy: Sharia Law, Secularism and the Social Compact
}

\author{
Zia Akhtar ${ }^{1}$
}

\begin{abstract}
This article considers the general points relating to the application of Sharia law which challenges legislators in the political instability of a number of Middle Eastern countries. The question explored is how governments of these countries who are facing discontent can work towards constitutional governance. As an example comparison is made between the Islamic Republic of Pakistan and Indonesia with the largest Muslim populations. In Pakistan an inherited Westminster Parliamentary system with a common law codified dated at the time of the British rule is supplemented by criminal penalties as present in the Hudood ordinances. These codes enforce punishments for some crimes and these were promulgated in the early 1980s during the reign of the Pakistani conservative military government. These different layers of jurisprudence do not accord with a uniform legal precedence and creates a clash between liberals and the fundamentalists who want an all pervasive Sharia law. The Pakistani legal canon of Islamic law has been restricted by the secular ideology of the state which has parallels in other Asian countries with a Muslim majority. However, there is an issue of compatibility of a secular ideology and the application of Sharia. It needs an exposition of thought that takes account of the enlightenment in Europe which led to the social contract theory in the 18th century. This theory rejects the narrow interpretation of divine authority and presents the jurist with a challenge to make modernize the laws. In recent times Muslim academics have adopted a critical approach against the tenets of conservatism in temporal Islam and called them unrepresentative of the true spirit of the Sharia. The present turmoil in the Arab countries has raised the question of legitimacy and the need arises to evaluate the principles of the Compact of Medina, which was proclaimed by the first Islamic state, and secondly, to enquire if the adoption of Sharia can be made contingent upon a consensus of popular sovereignty in order to make it binding in a contract between the ruler and the governed.
\end{abstract}

\section{Introduction}

The Muslim world is in turmoil because the regimes have not absorbed the lessons of the philosophical movement in 18th century in Europe which eventually terminated feudalism. While these regimes which are based on the nobility of birth are repressing the discontent to abort the support for popular power the lack of a consensus is all but clear. The divine rights of kings, emirs and sultans have showed only little in terms of change and are pressing their notion of power through inheritance as opposed to popular mandate.

\footnotetext{
${ }^{1}$ Member of Grays Inn. Specialist in Legal Philosphy and Constitutional law. Published in India Law Journal; Pakistan Law Journal; Sri Lanka Journal of International Law; Journal of Malaysian and Comparative Law; and Bagladesh Law Journal, etc.
} 
Currently there is a lack of constitutional legality and an investigation as to the cause of the recent upheaval has been launched. The purpose is to determine how to shape a policy in which the authority is based on a genuine observance of the Sharia and, at the same time, represents the authority in government. However, in order to achieve that, there has to be a scientifically rational exposition of the sacred law in an accountable manner, which is not being perceived as being dictated from the current rulers. The first step is to evaluate whether the modern concept of secularism can be fused with Islam and then formulate both the temporal and spiritual power into a single law entity. The evaluation takes Pakistan as a benchmark which was the most populous Islamic state before Indonesia took over the title. After the partition from India the state of Pakistan was founded in 1947, and became an Islamic state anchored on a secular ideology. Its laws were derived from the British statutes promulgated during the Raj's two hundred and fifty year span. The new nation adopted the constitution of Government of India Act 1935 which facilitated the inheritance of the colonial institutions into its body politic. ${ }^{2}$ In the 1970's Pakistan introduced the Sharia during a period when the nation was going through a process of Islamisation. This process caused, on one side, the fundamentalists to push for a full-fledged Islamic law against, on the other side, those who wanted to maintain a liberal Pakistan. The challenge for the legislators is how to enact laws which can fuse the principles of a religious birthright with those ideals that were considered as part of a liberal tradition at the time of the nation's independence. ${ }^{3}$

The methodology has to begin with the formulae of rights that enabled Pakistan to attain a civil society and to make it a test case for the democratic movements sweeping the Muslim world. This is a precondition for the rule of law that Pakistan has not achieved. It is necessary to understand that the military authority which has ruled Pakistan for most of its 62 years of existence maintained itself by an apparatus of unchecked power. This power apparatus has repeated itself on four times on account of "the need of the State" and left the civil administrations paralysed by the nations contradictory ideological principles.

Since its inception Pakistan has, in spite of being born on an Islamic ideal, had a government based on the Westminster constitutional model which is the norm in the Commonwealth. ${ }^{4}$ The nation is ruled by English common law, but the conflicts occur in its framework, such as the lacuna in the country's constitution which allow for the institutionalisation of Islamic law without any expert council of Fakihs, who may formulate the practical application of these noble expressions. ${ }^{5}$ The preamble to the 1973 Constitution states as follows:

\footnotetext{
${ }^{2}$ Mohammad Ali Jinnah, the founder of the state was a British barrister who was a cosmopolitan by upbringing and had his legal practice in Bombay.

${ }_{3}^{3}$ The Objectives Resolution was a resolution adopted on 12 March 1949 by the Constituent Assembly of Pakistan. The resolution, proposed by the Prime Minister Liaquat Ali Khan, proclaimed that the future constitution of Pakistan would not be modeled entirely on a European pattern but on the ideology and democratic faith of Islam.

${ }^{4}$ This is a pattern of Parliamentary democracy, where the head of state is a ceremonial figurehead who exercises the dejure executive power and a Prime Minister who is head of the ruling party.

${ }^{5}$ The concept of a fakih is of a legislator who is well versed in Islamic law. It is of particular relevance in Shia Islam and has been implemented in Iran by the Council of the Valeyet Faqih who is the ayatollah who holds the defacto power in the state. The scholar Vali Nasr contends that the ideal of an Islamic government ruled by the Ulema ' legal experts' depended upon the Greek philosopher's Plato's
} 
Whereas sovereignty over the entire Universe belongs to Almighty Allah alone, and the authority to be exercised by the people of Pakistan within the limits prescribed by Him is a sacred trust;

Wherein the principles of democracy, freedom, equality, tolerance and social justice, as enunciated by Islam, shall be fully observed;

Wherein the Muslims shall be enabled to order their lives in the individual and collective spheres in accordance with the teachings and requirements of Islam as set out in the Holy Quran and Sunnah;

Therein shall be guaranteed fundamental rights, including equality of status, of opportunity and before law, social, economic and political justice, and freedom of thought, expression, belief, faith, worship, and association, subject to law and public morality. ${ }^{6}$

These are the statements of intention which this essay will address in order to understand if it is possible for a cohesive body of Islamic law to exist in a modern state. The example of Pakistan will be a necessary benchmark because the Muslim countries from the Middle East and Malaysia are dominated by Anglo jurisprudence. The Arab nations which did not have a common law such as the Gulf countries (GCC) are now adopting English commercial law and shaping their banking systems in accordance with the British trust codes. ${ }^{7}$

In this article Indonesia has been chosen as the contrasting example and is like Pakistan a secular Muslim state but with a Roman- Dutch code. As most of the Indonesian archipelago was under Dutch rule from 1602 -1945 there is a presence of the colonial concepts of law in the legal system. There are the colonial statutes, Sharia codes and the customary law (adat) that are applied in the Indonesian legal system. The difference is marked because there is no system of precedence that is the norm in all Common law countries.

This paper will offer an example seeking to determine if the institutionalisation of an Islamic ideology can run in parallel with the secular system. The paper will trace the origin of the schools of thought in the middle ages, to the European enlightenment and the rise of thee conflict with the Fundamentalisms. In the modern state the two ideologies have not worked harmoniously and the answer can be found by exploring a formula which merges the temporal and spiritual medium into a coherent form of jurisprudence.

\section{Concept of an Immutable law}

\section{Foundations of natural law}

The reasoning that Islam is a divine source of law must mean that it is a natural law. In order for this to be established it must accord with the basic

\footnotetext{
Republic of the importance of the existence of "a specially educated `guardian` class led by a `philosopherking'”.The Shia Revival 2006 pg 126. (WW Norton; New York )

${ }^{6}$ Article 2 states that Islam is the State religion.

${ }^{7}$ The government of the UAE has imported the common law trust concept into local investment frameworks by establishing a trust law within the Dubai International Financial Centre (DIFC) that it set up by Federal decree in 2004. It then promulgated the Financial Free Zone Law that provides a regulatory framework to enact a Trust Law which may exclude the local laws. It jointly administers the application with the London Court of International Arbitration. http://www.inhouselawyer.co.uk/index.php/unitedarab-emirates/7945-use-of-trusts-for-asset-protection-in-the-uae
} 
tenets as derived from an immortal source. This notion is the very anti thesis of the materialistic determination and chimes with the ideal of a Supreme being, who has a power over all mankind. It emerged in Western theology initially with a doctrine of the 13th century jurist Thomas Aquinas who set out in his Summa Theologica ${ }^{8}$ four kinds of natural law principles. These are the eternal, natural, human, and divine law. He enumerated them as follows: Eternal law is the decree of God which governs all creation; Natural law is the human "participation" in the eternal law; Human is discovery of law by way of deliberation; and Natural law based on "first principles" are as follows: That good is to be done and promoted, and evil is to be avoided. All other precepts of the natural law are based on this.

The desire to live and to procreate is counted by Aquinas among those basic (natural) ie human values on which the whole value system depends. These are the fundamental guidelines for 'all benefactors of mankind'. They reject the transitional nature of state sanctions based on impulses and incremental changes known as 'positive law. It is only in divine law that natural law theory asserts that sustenance can be found to regulate governments and their officers in a polity, and that course of conduct is revealed in the scriptures.

This is a view that can be traced at source to Muslim civilisation that was at its theological height in the middle ages. ${ }^{9}$ It was then that the theories based on natural law with their roots in religion were first expressed. These relate to the period when Islamic law was developing under its basic tenets of Sharia law, that is a fundamental belief in the sources of law which in order of precedence are Quran and the Sunnah, ie the sayings of the Prophet per se. It is then open to the various schools of thought to develop the subsequent methodologies to deal with issues as they arise, according to their reasoning.

The concept of Istislah ${ }^{10}$ in Islamic law bears some similarities to the natural law tradition in the West, as exemplified by Aquinas. Whereas natural law deems good that which is known self-evidently to be a value, accordingly it tends towards the fulfillment of the person, istislah calls 'good' whatever is connected to one of five "basic goods". Al -Ghazali abstracted these "basic goods" from the legal precepts in the Qur'an and Sunnah: they are religion, life, reason, lineage and property. ${ }^{11}$

As Islam was split into the two main Sunni and Shia branches it was the former that gained ascendency among the mainstream Muslims. Among them the Maturidi school, the second largest body of principles of Sunni theology posits the existence of a form of natural law. ${ }^{12}$ This was based upon al -Maturidi 's belief that the human mind could know of the existence of God and the major forms of 'good' and 'evil' without the help of revelation. He gives the example of stealing which is known to be evil by reason alone, due to man's working hard for his property along with such prohibitions as killing, fornication, and

\footnotetext{
${ }^{8}$ Editor Norman Kemp Smith, Publisher: St. Martin's Press, New York 1965.

${ }^{9}$ The Muslim civilization had its four schools of jurisprudence come into prominence at this period of time. These were the Hanafi, Shafei, Habali and the Maliki.

${ }^{10}$ Oxford Dictionary of Islam states that the concept corresponds to Public interest. It is regarded as the object and purpose of Islamic law. It cites the Hanbal school of Islamic thought used this principles to seek the best solution in order to serve the general interest of the Muslim community. Use is limited to necessity and specific circumstances, and often requires the reinterpretation of relevant Quranic verses, hadith and fiqh materials

${ }^{11}$ Mawil Izzi Dien, Islamic Law: From Historical Foundations to Contemporary Practice, p. 69

12 They are the followers of the Hanafi school which predominates in Pakistan. Nearly $53 \%$ of Sunni Muslims are Hanafis. http//mb-soft.com/believe/txw/maturidi.htm
} 
drinking alcohol.

The largest school of thought of Sunni Islam, the Ashari rejected the natural law tradition. Its leading protagonist Al-Biruni, a scholar and mathematician, viewed natural law as the 'law of the jungle', and argued that the antagonism between human beings can only be overcome through studying divine scriptures, which he believed to have been sent through prophets. ${ }^{13}$

However, the leading theorist of the Islamic golden age Averroes (Ibn Rushid) set out in his treatise "Justice and Jehad"14 by way of a commentary on Plato's Republic, that the human mind can know of the unlawfulness of killing and stealing and, thus of the five maqasid or 'higher intents' of the Islamic Sharia to protect religion, life, property, offspring, and reason. The concept of natural law entered the mainstream of Western culture through his Aristotelian commentaries.

\section{Development of a Sacred law}

While there is a common ground in both Islamic teaching and Christian thought which is that there is a natural law upon which a value system depends they differ in terms of the revealed law where injunctions can proscribe certain acts which are considered as harmful and the course of conduct can be found in the scriptures. ${ }^{15}$ As a body of jurisprudence Sharia goes further and enacts codes which can be set down in a framework of laws. The concept of Sharia derives from concepts that deal with the 'directions' to the ruler and the process of enactment carries a binding obligation on the state.

In his treatise Understanding Islamic Law: From Classical to Contemporary, ${ }^{16}$ Professor Irshad Abdal-Haqq states Al-Shari'ah, is a literal term that means the "path which the believer has to tread". (45:13) ${ }^{17}$ He cites the application of the term as a reference to Islamic law as traced directly to the Qur'an, wherein the believers, are admonished by Allah (God) to follow the clear and right way, the path of Shari'ah: Then we put thee on the (right) Way of religion so follow thou that (Way), and follow not the desires of those who know not. (45:18)

The authority of Sharia stems primarily from the Quran and the Sunna (the Sayings of the Prophet Muhammad pbuh) As there are two other sources of law that are applied in this hierarchy which are Ijtehad (analogy) and Ijma

13 "He introduced an early scientific method in nearly every field of inquiry he studied. For example, in his treatise on mineralogy, Kitab al-Jamahir (Book of Precious Stones), he is "the most exact of experimental scientists", while in the introduction to his study of India, he declares that "to execute our project, it has not been possible to follow the geometric method" and develops a comparative sociology as a scientific method in the field. "Zia uddin Sardar in Science in Islamic philosophy. Routlege Encylopedia of Philosophy 2008 02-03.

14 "He is regarded as the primary interpreter of Aristotle and in his main theory was that there was no incompatibility between religion and philosophy, based on cause and effect. He defended philosophy against the attacks of those who condemned it as contrary to Islam ". Ibn Rushd-The Great Muslim Philosopher Who Planted The Seeds of European Renaissance. http.//www.aljadid.com/classics/0422. sallomn.html

${ }^{15}$ Islam has a different ethos and does not follow the Christian command of "Render unto Caesar the things which are Caesar's, and unto God the things that are God's" (Mathew 22.21)

${ }^{16}$ Edited by Amineh Beverly McCloud, Chapter 1, Islamic law : An Overview of its Origins an Elements ( Altra Mira Press, 2006) Page 4

${ }^{17}$ In his Dictionary of the Holy Quran, Abdul Mannan Omar interprets the terms as deriving from the "Quranic root" shara'a. These derivations express Shara'a as meaning "He ordained", "They decreed a law or Spiritual law" and a "System of divine law, Way of belief and practice. (45:18) Quran 45: 18 ( Noor Foundation International Inc, 2003 Pg 287) 
(consensus) it allows Islam a broad framework to interpret the verses of the divine texts. This has allowed Sharia or Islamic law to gain influence in the legal code in most Muslim countries. It is particularly prevalent in the personal status law which governs a set of regulations that pertain to marriage, divorce, inheritance, and custody of children.

The Islamic jurisprudence has developed over fourteen centuries and there are various schools of thought who are involved in the interpretation and application of the Sharia. There are two main branches which are the Sunni and the Shia, but the former has more impact as 85-90 percent of all Muslims belong to that tradition. The distinction has bearing on the geopolitical spread of the Islamic nations with some countries in the Middle East who have most people from the Shia denomination the most notable being Iran. The rest, including Pakistan and Indonesia, comprise people who follow the Sunni strand of Islamic jurisprudence.

In the Sunni category of islam there have been four main schools of thought who were Hanafi, Hanbali, Shafei and Maliki. These major schools on jurisprudence were founded by Imams trained in Quranic legal precepts between the ninth to eleventh centuries. Their lasting influence is still prevalent in the different Muslim states either entirely or partially. The Maliki school is followed by Egypt, where the great Al - Azhar university is based; ${ }^{18}$ Saudi Arabia is traditionally Hanbali although it has imbibed the teaching of a puritanical imam Abdal-Wahab, a reformer of the early 1800's. In Pakistan the Hanafi school is followed and in Indonesia the Shafei school of Sunni Islam.

\section{Conflict of laws and State Jurisdiction}

While the inhabitants of Pakistan are $90 \%$ Muslim the country's kernel of rules are based on English Common law that has been codified. The legislation in statutory form is set out in the Pakistan Code, but the Ministry of Justice, Law and Parliamentary affairs does publish individual Acts when these are updated in the light of amendments, and this is done through the Official Gazette. ${ }^{19}$ The codified civil and criminal laws are both encapsulated in the form of Acts, and there is an adversarial court procedure. While the country follows judicial precedent, there is no provision for juries in either branch of its jurisprudence. ${ }^{20}$

The state has separate civil and criminal courts, the higher courts form the middle tier and at the apex is the Supreme Court which is headed by a Chief Justice. According to the constitution of Pakistan, the court consists of one Chief Justice and 16 other judges. The Court has both de jure and de facto powers. The de jure powers are sanctioned by Article 58, which allows the dismissal of the national assembly by the President subject to the approval of the Supreme

18 The AlAzhar university is regarded as the world's oldest university and was founded in the 7th century. It has been a mosque and a seat of learning for Sunni Islam. It has benefited from the Mughul attacks on central Asia and the shrinkage of Muslim rule in Andalusia, Al-Azhar became the only shelter for the scholars who were forced out of their homeland. Those scholars helped Al-Azhar to reach the apex of its glory during the eighth and ninth centuries A.H (14th and 15th centuries A.D. http//www.islamfortoday. com/alazhar.htm

${ }^{19}$ The Federal Laws of Pakistan are published by the Government in a document called the Gazette of Pakistan. The law reports are compiled in the Pakistan Legal Decisions (PLD) and the Pakistan Law Journal (PLJ), that also contain the statutes in their statutes sections.

${ }^{20}$ The current code is spread over twenty-one (21) volumes dating from the year 1836 C.E. Volume twenty-one, the last published volume, contains the laws made up to the year 1988. Code volumes for the years after 1988 are yet to be published and made available. 
Court. The de facto powers are in the gift of the Court and allow it to hear judicial review as when the military dictatorships have abrogated the constitution and issued Legal Framework Orders. ${ }^{21}$

According to Article VII, Chapter 2, of the Court's constitution judges in the Supreme Court are appointed by the President after consultation with the Chief Justice. The Supreme Court judge needs to be a citizen of Pakistan and, he also either needs to have an accumulative experience of at least five years as a judge of a High Court or of fifteen years as an advocate of a High Court.

The seeds of an Islamic jurisprudence were sown when the military government of General Ziaul Haque first came to power in a coup de etat in 1977..$^{22}$ In February 1979, the President who was also the Chief Martial Law Administrator had abrogated the civilian constitution and promulgated a new legal code for Pakistan. This was based on Islamic law and had two cornerstones, firstly the criminal law sanctions entitled the Hudood ordinances and, secondly, the establishment of the Federal Shariat Court in 1980 to hear appeals arising from the new code The Court was also vested extensive other powers and it was within the discretion of the court of first instance to decide whether to try a case under civil or Sharia law. If the latter, then the appeal process heads to this Court, rather than to the high courts.

The powers of the FSC are extensive as it can of its own motion or through petition by a citizen or a government (federal or provincial), examine and determine as to whether or not a certain provision of law is repugnant to the injunctions of Islam. An appeal against its decisions lie to the Shariat Appellate Bench of the Supreme Court, consisting of 3 Muslim judges of the Supreme Court and 2 Ulema (religious scholars), appointed by the President. If a certain provision of law is declared to be repugnant to the injunctions of Islam, the government is required to take necessary steps to amend the law so as to bring it in conformity with the injunctions of faith. ${ }^{23}$

The Objectives Resolution of the preamble of the FSC's Constitution was made a part of its substantive provisions by the insertion of Article 2A in 1985, thereby requiring all laws to be brought into consonance with the Quran and Sunnah. Part IX of the Constitution is entitled "Islamic Provisions" and provides for the eventual Islamization of all existing laws, reaffirming that no laws repugnant to the injunctions of Islam are to be enacted

${ }^{21}$ The previous military government of General Musharaff promulgated LFOs on two occasions during its 11 years rule by suspending the 1973 constitution and set out emergency laws by means Provisional Constitutional orders. On both occasions they were challenged in the Supreme Court.

${ }^{22}$ When he ascended into power on 5th July 1977 the General established called his introduction of Shariat benches as an attempt to establish the Nizam e Mustapha ( the Prophet's system). In the absence of a parliament under a military government General Zia decided to set up an alternative system Majlis e Shoora in 1980.The Shoora was to act as a board of advisors to the President. All 284 members of the Shoora were to be nominated by the President. The Pakistan Parliament under a civilian order is still known by the title of Majlis e Shoora.

${ }^{23}$ The court also exercises revisional jurisdiction over the criminal courts, deciding the criminal cases that concern the Islamic injunctions. cases. The decisions of the court are binding on the High Courts as well as subordinate judiciary. The court appoints its own staff and frames its own rules of procedure and the status of Islamic law is determined by Article 1 of the 1973 Constitution which declares that Pakistan's official name shall be the Islamic Republic of Pakistan, and Article 2 declares Islam the state religion. Chapter 3A establishes the Federal Shariat Court. The FSC consists of 8 Muslim judges including the Chief Justice.. These Judges are appointed by the President of Pakistan choosing from amongst the serving or retired judges of the Supreme Court or High Court or from amongst persons possessing the qualifications of judges of a High Court. 
The conflict between the parallel existence of codes of law first emanated itself when the legislative assembly of the North West Frontier province passed a controversial bill in the course of enacting Islamic law in that region. This bill was a follow up to the Shariat Act that was promulgated in the NWFP Assembly in 2003 and the enabling mechanism was to be the Hisba bill. The bill was referred by the provincial governor to the President after some members of the Assembly protested that it went against the secular ideology of Pakistan. This brought the executive's intervention in the judicial alter of the Supreme Court. General Musharaff, as President in 2066 went to the aid of the legislators who wanted to outlaw the bill by calling on Chief Justice Iftikhar Chowdhary to annul it for breaching Pakistan's secular ideology. This brought the attempt to legislate Sharia in Pakistan by legislative means to an end. ${ }^{24}$

This set in motion a national crises that led to the suspension of the Chief Justice in 2007 when General Musharaff, dismissed the Chief Justice from his post. The reason was cited as misconduct of the judge and led him to being made non functional. However, this did not mean that he resurrected the bill or asked for it to be referred to the Supreme Court again for consideration. The General had to wait for the Supreme Court to declare the dismissal illegal and for him to be restored until the emergency in October in the same year which led to the dismissal of the judge along with his colleagues for the second time to ensure the election of the President for another term. ${ }^{25}$

\section{Customary Legal Codes and Militant Islam}

The dramatic events that the abortive Hisba bill unfolded came in the background of the rugged landscape of the North West Frontier province where the instigators of the proposed legislation live. They are the ethnically distinct Pushtons who are separate from the mainstream Pakistanis by their traditional and rural life patterns. ${ }^{26}$ The Pushtons who are labeled as obstructionist by the urbane Pakistanis follow the code of Pakhtonwali, that is a code of honour that serves as a bastion of puritanism in the Frontier province. It has a stronghold in the mountainous badlands, which are the epicentre of the 'war against terrorism' that is being conducted in a pocket of the country where the indigenous people share a porous border with Afghanistan.

The Pushtons regard themselves as brethren of those kinsmen separated by the Khyber Pass. They are engaged in a struggle where their version of

${ }^{24}$ President, General Musharaff, who acted as the Referring Authority to declare that under Article 186 of the Pakistan constitution the purported legislation was "an infringement of the country's secular constitution". The Court ruled that two Sections viz. 2(11) and 3(2) of Hisba Bill 2006 were not deemed to comply with the constitution of Pakistan. did not comply with the earlier opinion of the Supreme Court.

${ }^{25}$ The dismissal invoked the Clause five of Article 209 of Pakistan Constitution that states if the president is of the opinion that a judge of the Supreme Court or of a High Court (a) may be incapable of properly performing the duties of his office by reason of physical or mental incapacity; or (b) may have been guilty of mis conduct, The president shall direct the Council to inquire into the matter. Acting Chief Justice Dogar dismissed the final challenge against Musharraf's candidacy. Acting Chief Justice Dogar dismissed the final challenge against Musharraf's candidacy.

${ }^{26}$ Most are sedentary or semi-sedentary farmers and perhaps two million or more are nomads. The Pushton composition is made up of a largely tribal society, and most division are intra-tribal. This has been the case since the time of the indigenous Durrani dynasty established in Kabul in 1747 and there have been conflicts between (western) Durrani and (eastern) Ghilzai Pashtuns. http//.www.faqs.org/ minorities/south.-Asia/patterns.html 
customary Islamic law collides with the moderate and often emasculated versions of Islam of the liberal sectors of the Pakistani population. The Pushton number about 20 million, of whom nearly five million on the FATA (Federally Administered Territorial Agencies) in Pakistan. It is from these lands that the Taliban have emerged that are strict adherents of a Sharia code that is based on an understanding that it has to be formulated and applied in an undiluted manner.

The fraternal ties of the Pushtons are maintained by the preservation of the social convention of Pakhtonwali, that for them supersedes all other laws. This is a binding set of ethics that governs their lives and provides a bedrock to their seminal existence as a traditional society. ${ }^{27}$ It prescribes loyalty to the family and tribe over that of the state. The practitioners of this code are invariably very religious and observe Islamic tenets assiduously. The origins of this code go back to the days of the Mughal emperor Aurangzeb, in the 18th century when formidable military forces were required to quell Pushton nationalism. ${ }^{28}$

The norms are enforced through the loya jirga, that acts as an informal court made up of elders of the clans who sit in council prior to judgment. The Pakistan government's writ runs out in the tribal regions, which are known as the Federally Administered Tribal Areas (FATA), and the only representative is an agent or Malik, who are attached to seven of the largest tribes assisted by 3 Tehsildars in each agency enforcing justice under the Frontier Criminal Regulations enforced first in 1893 and then revised in $1905 .^{29}$

These were promulgated in 1903 by the British, and they serve to impose severe penalties for infractions on whole clans or affiliates of the alleged criminal perpetrator. The evidential requirements are satisfied with simply "solid supporting information" for the authorities under the Malik or the 3 Tehsildars acting under him in dispensing summary justice. ${ }^{30}$ There is no recourse to appeal to any of the courts in Peshawar the province's capital, and this has caused the procedures enforced under the FCR to be criticised as a fundamental breach of human rights.

The Pushtons regard the 1519 mile border with Afghanistan demarked by the British as the Durand line in the 1890s as an artificial boundary. It goes against the concept of their one nation concept that was idealized by the poet Sahibzada Abdul Latif of Khost. ${ }^{31}$ The region has become a hot bed of support for the Taliban insurgency since the US invasion of Afghanistan, and has been dubbed as the 'lawless' territory with cross border raiding by the tribes on American fortified bases.

However, in recent times the militancy has surfaced within Pakistan proper in the former principality of Swat, which was given political autonomy

${ }^{27}$ The central tenet of the code is 'Itbar' which means trust, or guaranteed assurance or is the arch of society which is governed by un-written laws or conventions and ruled by consensus. http//www. khyber.org/culture/pashtunwali.shtml

${ }^{28}$ Khushal Khan Khattak was the leader most responsible for the nationalistic growth. 1723-1789 He was a poet warrior and spiritual leader who was a resistance leader of the people. http://www.afghan. web.com/bio/yest/kkk.html

${ }^{29}$ Under Chapter II the Provincial Government may appoint any Magistrate or Additional District Magistrate without any limit of time

${ }^{30}$ An instance of that is the application Section 393 of the Code of Criminal Procedure 1905 that can inflict upon him a sentence of whipping in addition to any other punishments to which he may be sentenced.

${ }^{31} \mathrm{He}$ was one of the two representatives of the Afghanistan government when the Durand treaty was signed in 1893 
before the armed forces crackdown began this spring. The bone of contention is that the Pakistani Taliban, who are composed mostly of the maadressa educated Pushtons want to propagate the spread of Sharia all over the Pakistani state. ${ }^{32}$ In 1947 there were only 189 maadressas in Pakistan, which by 2002 went up to 10,000-13,000 unregistered such schools with an estimated 1.7 to 1.9 million students. A 2008 estimate puts this figure at "over 40,000", most of whom cater for the out of which most cater to the dominant Sunni sect.

\section{Criminal Law and The Liberal Backlash}

The conflict that this has engendered arises from the seminary educated Taliban and their mainstream sympathisers and the liberal rulers of Pakistan who come from the westernised elite of the country's English medium schools. The bone of contention in terms of the legislation that the Pakistani state has enforced is plank of statutes collectively known as the Hudood Ordinances. These laws were controversial from their very inception when Gen Ziaul Haq introduced them. ${ }^{33}$ This was the implementation of what he believed was the establishment of an "Islamic" system of justice in the country. These legal instruments came into force as the Prohibition (Enforcement of Hadd) Order 1979 -P.O No 4 of 1979; The Offence of Zina (Enforcement of Hudood) Ordinance, 1979 - Ordinance VII of 1979; and Enforcement of Hadd Ordinance, 1979 Ordinance VIII of 1979. The third is divided into four sections that regulate propriety; qazaf [false accusations of adultery); adultery; and prohibitions. ${ }^{34}$

In essence the Hudood is one of the four categories of punishment in Islamic Penal Law, which exists in addition to Qiyas, that corresponds to retribution; Diyya compensation paid to the heirs of the victim, and Tazir that is punishment usually corporal administered at the discretion of the judge. The Hudood offenses comprise theft, highway robbery, illegal sexual intercourse, wrongful allegations of impropriety, drinking alcohol, blasphemy and apostasy.

The breach of Hud prohibitions are defined as acts that go against the "claims of God," and therefore the sovereign has a responsibility to punish them. All other offenses were defined as "claims of [His] servants," and responsibility for prosecution rested on the victim. This includes murder, which was treated as a private dispute between the murderer and the victim's heirs. The heirs had the right to compensation called diya and to demand execution of the murderer i.e. qisas, but they could also choose to forgive. ${ }^{35}$

The criticisms levelled at their imposition in Pakistan was that ordinances make no distinction between adultery and rape and, an example, is that a woman who is a victim of rape must bring before an Islamic court the testimony of four males adults who witnessed to and can testify the act was carried out using violence. According to the ordinances, if the victim is unable to produce

${ }^{32}$ Islamic seminaries teach mostly Islamic subjects leading to graduation as a cleric (called maulvi, maulana or mulla) in Pakistan.They were colleges of learning in the middle east in the 11th century, and supplied physicians, administrative officials, judges and teachers. George Makdisi, The Rise of Colleges. Institutions of Learning in the Islam and the West 1981 Edinburgh University Press. Pp 10-24

${ }_{33}$ General Zia's Martial Law Proclamation stated that all orders, ordinances and Martial law regulations were to become law, when he assumed power. Gazette of Pakistan, Extraordinary Part I, 5th July, 1977.

${ }^{34}$ The Hudood Ordinances are now obsolete as WPAct 2006 affirms the laws relating to zina and qazf in conformity with the stated objectives of the Constitution and the injunctions of Islam

${ }^{35}$ World of Islam Summary of Hudd punishments. Sheikh Munnajid http://www.angelfire.com/ mo2/scarves/hudud.html 
these witnesses, she may find herself accused of adultery and condemned to imprisonment. ${ }^{36}$

In Pakistan the case of Zafra $\mathrm{Bibi}^{37}$ a case went to trial against the complainant who had alleged that she had been raped. Zafran Bibi after 13 years of marriage to Naimat Khan of Kari Sher Khan village in Kohat who had been convicted of murder and awarded 25-years imprisonment. She continued to live with her in-laws and was harassed on numerous occasions by her husband's brother, Jamal Khan. She complained about her behaviour to her mother-in-law Zar Bibi, who instead laid the blame squarely on the young woman's shoulders and ordered Zafran to mend her ways.

She was subsequently raped by Jamal Khan, and the matter was buried again, but when she became pregnant she had no option but to complain direct to the authorities. The ordinances facilitated her trial under adultery and she was convicted of Zina. However, as the campaign to change the laws gathered momentum and the knowledge of her ordeal became news it was the Federal Shariat Court that overruled the appellant court's ruling, quashed her conviction and released her. The Court ruled that the woman if coerced into committing Zina shall not be liable under the Hud laws.

This was a landmark judgment and the Hudood ordinances have since been deemed obsolete based on the charge that this portion of Sharia is incompatible with the humanist or Western understanding of human rights. The critics of this interpretation of Hudood laws which punishes the complainant were vindicated when the government promulgated the Protection of Women Act in 2006. This provision has made amendments to the Hudood laws by bringing rape under the Pakistan Penal Code, 1860 (as amended in 1965 and 1980) which is not based on Sharia law.

There is a senior scholar on Islamic law Gerhard Endress who has stated that at the time of advent of Islam, several social reforms happened in which a new system of marriage and family, including legal restrictions such as restriction of the practice of polygamy was conceived . Endress says: , "The social system ... build up a new system of marriage, family and inheritance; this system treated women as an individual too and guaranteed social security to her as well as to her children. Legally controlled polygamy was an important advance on the various loosely defined arrangements which had previously been both possible and current; it was only by this provision (backed up by severe punishment for adultery), that the family, the core of any sedentary society could be placed on a firm footing. " ${ }^{8}$

\section{Comparison with Indonesia}

\section{Secular state framework}

The constitution of Indonesia (Undang Undang Dasar) was framed in 1945 after the country gained independence from Dutch rule. The jurisprudence is

${ }^{36}$ The Council of Islamic Ideology (CII) in 13/12/05 agreed to amend the controversial Hudood ordinances to bring it in accordance not only with the Quran but also the Penal Code and the Criminal Procedures Code, a CII press release said. This last decision is very important, given the results of a survey which revealed there are around 200,000 pending cases linked to the ordinances. In Lahore alone, the Federal Court must pass judgment on 1,400 cases: this has led to the unjust detention of those awaiting sentencing, most of them women. This was later enforced through the Women Protection (Criminal Law Amendment) Act in 2006.

${ }^{37}$ http:www. Dawn.com/2002/08/21/top12. tom

${ }^{38}$ Gerhard Endress, Islam: An Introduction to Islam, Columbia University Press, 1988, p.31 
based upon Dutch colonial law, Islamic law, and adat (customary law) and all three exist up until today. From the Dutch the civil code (Burgerlijk Wetbook) and the Civil Procedure Law (Het Indische Reglement) have been inherited .

There are five tenets that compose the national ideology of Indonesia called Pancasila: the belief in One God Almighty, that the country's humanity was just and civilized, that Indonesia is a unitary whole, that democracy should be guided by the wisdom of representative deliberation, and that all Indonesians should enjoy social justice. This is underscored by Article 29 of the Constitution.

The advocates of Sharia law have argued that the first principle should require "the belief in One God Almighty and obligate Muslims to conform to Sharia law" but this was not accepted by the 'founding fathers' of the new state who omitted the second part after much deliberation.

In August 2002 there was another attempt to have the Article amended in August 2002 but it was unsuccessful as the religious parties did not gain sufficient support to get it passed. This would have entrenched the Sharia as one of the principles of the Pancasila but it was not passed by the Peoples Consultative Assembly . To some theorists it has shown that Indonesia practices the substantive approach to Sharia as opposed to the formal approach. ${ }^{39}$

During the period 1999-2002 the Indonesian constitution went through many reforms some of which limited the powers of the executive level of the President and Vice President who exercised power during two terms. It prescribes a strong executive branch where the President and Vice President exercise power and both officers are electable for only two terms. ${ }^{40}$

The Indonesian judicial system comprises of four types of courts which are: the Courts of General Jurisdiction, ${ }^{41}$ the Religious Courts, the Military Courts and the State Administrative Courts. In addition there are several types of courts under the oversight of the Supreme Court (Mahkamah Agung). The Religious courts settle religious jurisdiction and their role has been expanding from the economic sphere where they adjudicate in matters of charitable and personal status laws.

${ }^{39}$ In Religion and the Indonesian Constitution : A recent debate. Journal of South Asian Studies. Pages 419-440 October 2005. National University of Singapore the author Nadirsyah Hosen states that " there can be legitimate use of religion as an instrument of public policy ". He defines the substantive approach as " an emancipated understanding of the Syriah, stressing its original meaning as a 'path' or 'guide' rather than a detailed legal guide". He advocates the recovery of Ijtihad as a process of independent legal reasoning in order to do justice both to modern needs and the classical origins of the concept.

40 The 1945 Constitution provides for a number of constitutional bodies two of the most important are the People's Consultative Assembly (Majelis Permusyawaratan Rakyat or MPR) and the House of People's Representatives (Dewan Perwakilan Rakyat or DPR). The DPR is 500-strong and consists of elected and appointed representatives whose main function is to make legislation and hold the President and his ministers accountable.

${ }^{41}$ There are about 250 State Courts throughout Indonesia, each with its own territorial jurisdiction. In the Appeal process the State Court decides before the High Court (Pengadilan Tinggi), of which there are around 20 throughout Indonesia. The High Court serves as a district court of appeal and appellants cans in some instances raise an appeal to the Supreme Court located in Jakarta. The Supreme Court can hear a cassation appeal (kasasi) which is a final appeal from lower courts. However, it can also conduct a case review (peninjauan kembali) if, for example, new evidence is found which justifies a re-hearing. There is also a State Administrative Court (Pengadilan Tata Usaha Negara) which hears administrative law cases filed against the government. In the 2001 constitutional amendments, provision was made for the creation of the Constitutional Court (Mahkamah Konstitusi). Among other matters, this Court has the jurisdiction to hear cases involving the constitutionality of particular legislation, invalidating a general election, as well as impeachments against the President. 
There is an increasing body of laws that the Religious Courts are now covering and according to the treatise Sharia Law as a System of Governance in Indonesia: The Development of Islamic Financial Law by H Juwana, Y Barlinti and YK Dewi ${ }^{42}$ as follows: The application of Islamic law in Indonesia prior to Independence was impeded by the application of the Receptie Theorie 1929 which is included in Article 2 that the Islamic law only applied where one of the parties to the disputes was a Muslim.

They then elaborated on the development of Sharia law in Indonesia by broadening the jurisdiction of the Religious courts to include hearing of commercial disputes. Juwana et al cite the Law no 3 of 2006 amending the Religious Courts Act Article 49 to increase the powers of these courts in the management of Zakat in 1989 and in 2004 of the Waqfs.

The Islamic economic activities continue to be based on currently applicable regulation. However, endeavors continue to be made for the improvement of regulations dealing with their Islamic economic activities.

The infusion of the Sharia law in the area of finance, commercial and charitable law augments the personal status law that has been implemented by way of family law reforms. However, the controversy and the infringement of fundamental rights arise when the criminal law codes are introduced in the jurisprudence of the state. It is this area that has caused the collision of ideals.

\section{Policing and Imposing Corporal Punishment}

In 2001 the Indonesian government enacted the Special Autonomy Law in the Aceh province. ${ }^{43}$ This implementation has allowed the administration of the criminal justice system into the management of the Aceh authorities. This includes the Sharia police force (Wilayatul Hisbah,) and the sentencing and the sanctions that are applicable in accordance with Sharia law. The courts have imposed the punishments as prescribed in the form of whipping, warnings and shaming of people convicted of crime or immorality.

The issues that have been brought to light have been by western human rights organizations who have accused the Aceh government of a brutal system of criminal penalties. At the end of last year the Human Rights Watch prepared a damning report in which they accused the authorities of conducting fundamental rights violations. The 89 page report Policing Morality: Abuses in the Application of Sharia in Aceh, Indonesia, ${ }^{44}$ was released on December $1^{\text {st }}$ 2010. The report documents the experiences of people accused of violating Sharia laws prohibiting "seclusion" and imposing public dress requirements on Muslims and is critical of these rules and the strict interpretation of Islamic norms of public decency.

The report is critical of the adoption of the five laws which range from charitable giving, to gambling, to Islamic ritual and modest Muslim behaviour. The HRW report states that the laws are selectively enforced - rarely if ever applied to wealthy or politically connected individuals. This is the latest and most glaring example of the conflict between modernity in the Indonesian landscape which is reminiscent of the clash between the Islamic trends

\footnotetext{
${ }^{42}$ Winconsin International Law Journal, Vol 25 No 4, 2008 page 774 -794

43 Special Autonomy Law on Nanggroe Aceh Darussalam (NAD) law no 18 of 2001. www.kbricanberra.org.au/s.../aceh/aceh_specautonomy.htm - Cached - Similar

${ }^{44}$ www.hrw.org/en/news/.../indonesia-local-sharia-laws-violate-rights-aceh
} 
and liberal doctrines of tolerance for diversity that has been played out in Pakistan.

\section{Emergence of a Critical Theory}

The incompatibilities between the way that Islamic law is practised in many countries and the interpretation of universal human rights documents has led Tariq Ramadan, ${ }^{45}$ a leading jurist based at Oxford University to state that there should be an international moratorium on the Hudood laws until greater scholarly consensus can be reached. He sets out his doubts about the various texts and their respective "degrees of recognized authenticity, that make reference to corporal punishments" and the sum total of the Islamic scriptural sources on the penal laws that can be encapsulated as the hudood laws. These he casts as based upon the possible interpretations and the clear divergences (al ikhtilâf) in the history of the Islamic law and in the contemporary era.

Ramadhan states as follows "Considering that the opinions of most scholars, regarding the comprehension of the texts and the application of hudud, are neither explicit nor unanimous (indeed there is not even a clear majority), and bearing in mind that political systems and the state of the majority Muslim societies do not guarantee a just and equal treatment of individuals before the law, it is our moral obligation and religious responsibility to demand for the immediate suspension of the application of the hudûd which is inaccurately accepted as an application of "Islamic sharî'a". This call doubles itself with a series of basic questions addressed to the body of Islamic religious authorities of the world, whatever their tradition (sunnî or shî̀î), their school of thought (hanâfî, mâlikî, ja'farî, etc.) or their tendencies (literalist, salafî, reformist, etc.)"

He then enquires as to what are the conditions (shurût) stipulated for each of the penalties by the sources themselves, the consensus of the scholars (al ijmâ'), or by individual scholars through Islamic law history and jurisprudence (fiqh), and the divergences on the stipulations and what "extenuating circumstances" were sometimes elaborated by religious authorities throughout history, or within the different schools of thought? Ramadan responds to that question as follows "What are the socio-political context (al wâqi') that was always considered by the ulamâ' as one of the conditions needed for the application of hudûd. The importance of this question is such that it demands special treatment (and participation within the debate from intellectuals, notably those who are specialized in the social sciences). In which context today is it possible to apply hudûd? What would be the required conditions in terms of political systems and the application of the general legislation: freedom of expression, equality before the law, public education, eradication of poverty and social exclusion? Which are, in this domain, the areas of divergence between the legal schools and the ulamâ' and on what are these disagreements based? Studying these questions are meant to clarify the terms of the debate with regards to the interpretative latitudes offered by the texts, while simultaneously taking into account the determining state of contemporary societies and their evolution. This intra-community reflection requires from the start a double understanding of the texts and contexts, in keeping solemnly with the objectives of the Islamic message. On the whole, this must allow us to respond to the questions of what is applicable (and according

\footnotetext{
${ }^{45}$ Tariq Ramadan. An International call for a Moratorium on corporal Punishment, stoning and the death penalty in the Islamic Word. 30/3/2005 www.tariqramadan/article264.
} 
to which methods) and what is no longer applicable (considering the required conditions are impossible to reestablish as well as the fact that societal evolution is clearly moving away from the required ideal). This undertaking requires, from within, rigour, time and establishing spaces of dialogue and debate, nationally and internationally, between the ulamâ,' Muslim intellectuals and inside the Muslim communities since this matter is not only about a relationship to the texts, but equally, to the context. In the interval, there can be no justification for applying penalties that sanction legal approximations and injustices such as is the case today. A moratorium would impose and allow a basic debate to unfold in serenity, without using it as an excuse to manipulate Islam. All injustices made legal in the name of Islam must stop immediately." 46

\section{Social Compact and the First Islamic Constitution}

However, in order to discover if there can be an implementation of the "Had" laws in the modern world the intellectual ferment in the west that separated religion and politics has to be analysed. The post renaissance period was the dawn of legal philosophy which began to mirror that being witnessed in science and technology. It was an attempt to rationalise society and man's emerging role in social strata that the first ripple against the autocracy in the corridors of power surfaced. The originating ideas for civil society that rejected orthodox interpretations of religion flowed from the writings of Voltaire, Diderot, D'Alembert in the cause of enlightening the masses against established religion.

Its most profound exponent was J-J Rousseau who was also unlike his contemporaries a conservative albeit a deist. He stated in the Social Contract, $1762(1)^{47}$ as follows:

Man is born free and is everywhere in chains. One thinks of himself the master of others, and still remains a greater slave than they. How did this change come about? I do not know. What can it legitimate? That question I think I can answer. ${ }^{48}$

He then goes on to assert the premise of his enquiry:

I mean to inquire if, in the civil order, there can be any sure and legitimate rule of administration, men being taken as they are and laws as they might be. In this inquiry I shall endeavour always to unite what right sanctions with what is prescribed by interest, in order that justice and utility may in no case be divided. ${ }^{49}$

Rousseau establishes a test to address the nepotistic rule that leads to the unravelling of the feudal modes of government that encapsulates the legal, social economic and political systems. It enables freedom of thought, including religious expression that is contingent on promoting public morality. This formulation lays the basis of its enquiry that every government must have a mandate to govern and it means that there is a constituency upon which it pivots in drawing legitimacy. The ideal that he expresses is that of a social compact.

\footnotetext{
${ }^{46}$ Ibid

${ }^{47}$ Dent Publishing Company, 1923 (original publication date 1862)

${ }^{48}$ Ibid Chapter 1

${ }^{49}$ Ibid Chapter 1
} 
However, the origins of this doctrine can be traced by reference to the Islamic faith in its classic formulation to the Compact of Medina, which is referred to as first Constitution of Muslims and merged the temporal and the spiritual powers of the ruler. It came about when the Prophet Mohammad (PBUH) migrated from Mecca to Yathrib in $622 \mathrm{CE}$, and established the first Islamic state. This led to the ten years span when the Prophet became the leader of the emerging Muslim polity in this city. ${ }^{50}$

He began exercising jurisdiction over Muslims as well as non-Muslims within the city. The legitimacy of his rule over Medina was based on the compact of Medina, which was a trust vested in him by the divine decree of being God's messenger. His rule over the non-Muslims of Medina was validated by virtue of the tri-partite agreement that was signed by the Muhajirun (Muslim immigrants from Mecca), the Ansar (indigenous Muslims of Medina and the Yahudi (Jews) who were granted a constitutional partnership in the making of the first Islamic state. $^{51}$

The compact of Medina provides an historical example of a theoretical construct that has shaped legal theory. This entered the thesis of Rousseau who issued an abstract concept of an agreement between people in the state of a nature that leads to the establishment of a modern state. In the state of nature people are free and are not obliged to follow any rules or laws. They are essentially sovereign individuals, but through the social contract they surrender their individual sovereignty to the collective and create the community. This organisation then acts as an agent of the sovereign people, exercising the sovereignty that has been delegated to it by the people through the social contract in order to realize the aspiration of the people enshrined in the objectives of the social contract. ${ }^{52}$

However, the social compact as an ideal has very few instances in western statecraft. This appears to be a document based on the origins of a state whose legacy has survived in the Islamic jurisprudence and can provide the grounding of a legal framework. The question then can be asked if that can be transferred and if the requirements of a civil society can meet with the universal set of human rights values.

It has been argued by Muslim theorists that the constitution of Medina is deemed to have established a pluralistic state, a community of several communities. It promised equal security to all and all were equal in the eyes of the law. In The Compact of Medina: A Constitutional Theory of the Islamic State MA Muqtedar states: $:^{53}$ "The principles of equality, consensual governance and pluralism are enmeshed in the compact of Medina states. The compact of Medina serves the dual function of a social contract and a constitution. Clearly the compact of Medina by itself cannot serve as a modern constitution. It would be quite inadequate since it is a historically specific document and quite limited in

\footnotetext{
${ }^{50}$ This is known as the Charter of Fundamental Rights because in it were expressed the rights of the minorities which included the Jews and Christians.

${ }^{51}$ The journey that the Prophet undertook from Mecca to Medina as it became known was the culmination of the Hijrat ie Migration and it is at this point that the Islamic calendar begins

52 The ideal of Rousseau finds a basis in the Ibn Ishaq quote on the compact of Medina. He states : The quote states another principle: When you differ on anything (regarding this Document) the matter shall be referred to Allah and Muhammad (may Allah bless him and grant him peace). The reference to the covenant infers from Ibn Ishaq that the state of nature was now past. 30th, 2001

${ }^{53}$ The Compact of Medina, MA Muqtedar Khan, Published by the Mirror Iinternational on May
} 
its scope. However it can serve as a guiding principle to be emulated rather than a manual to be duplicated. The compact of Medina also illustrates what should be the relationship between the revelation and a constitution. Muhammad (PBUH) if he so wished could have merely indicated the truth revealed by Allah (PBUH) shall serve as the constitution of Medina or the basis for the new community and force this revelation upon non-Muslims. But if he did that then he would have ruled Medina with the authority of Allah behind him but without the complete consent of those under his rule. Muhammad (PBUH) in his great wisdom demonstrated a democratic spirit quite unlike the authoritarian tendencies of many of those who claim to imitate him today. He chose to draw up a historically specific constitution based on the eternal and transcendent principles revealed to him and sought the consent of all who would be affected by its implementation. In simple terms, the first Islamic state established in Medina was based on a social contract, was constitutional in character and the ruler ruled with the explicit written consent of all the citizens of the state. Today we need to emulate Muhammad (PBUH) and draw up our own constitutions, historically and temporally specific to our conditions and based on the eternal and transcendent principles revealed by Allah (SWT)."

\section{Charter of Fundamental Rights}

This leads directly to the question whether Islamic jurisprudence can satisfy the test of human rights as enshrined in the UN Declaration of Human Rights 1948. The issue of which rights are legally enforceable is an important one and the proponent of this argue on the basis of a 'social contract' that all human rights have legal rights. It is a concept that has been examined in an Islamic forum which dealt with the dimension of human rights in the context of the enshrined sacred text of the Quran. These were encapsulated in an Islamic Human Rights Declaration of Cairo in $1990 .^{54}$ This led to the framing of an idealistic document that states in its preamble the contribution of Islam to mankind's effort to protect man from "exploitation and persecution, and to affirm his freedom and right to a dignified life in accordance with the Islamic Shariah".

Article 10 of the Declaration states: "Islam is the religion of unspoiled nature. It is prohibited to exercise any form of compulsion on man or to exploit his poverty or ignorance in order to convert him to another religion or to atheism." Thus there is a clear demonstration to bring into line with natural law reasoning and allow a person to develop their own rational faculties and understanding of religion and civic sense. It is also an expression of toleration and benevolence as an article of faith rather than a property of any particular religion.

Article 23 states that (a) Authority is a trust; and abuse or malicious exploitation thereof is absolutely prohibited, so that fundamental human rights may be guaranteed. (b) Everyone shall have the right to participate, directly or indirectly in the administration of his country's public affairs. He shall also have the right to assume public office in accordance with the provisions of Shari'ah. This seems a clear denunciation of arbitrary government and is a proclamation of a democratic ideal. It calls for participation and subjects the ruler to the wishes of the people.

${ }^{54}$ Adopted and Issued at the Nineteenth Islamic Conference, of Foreign Ministers in Cairo on 5 August 1990 
The Article 24 clarified that "all rights and freedoms stipulated in this Declaration are subject to the Islamic Shari'ah". The onus is on the constitution of the state to set out these provisions guarantee the basic rights. It is fundamental law of practice as well as custom and whose source is the religious doctrine of a divinely inspired law. This is a proclamation of natural rights under the notion of a religious inspiration that derives its source from the Sharia principles.

In essence the Declaration reverts to the Compact at Medina that has been cited as an authentic version of an Islamic state. The Cairo Declaration mentions the "an alliance or a federation between the various peoples of the book" 55 They are described as equal citizens with Muslims who are deemed to pay a special tax to the state, but are excused from participating in its wars. It was a key tenet in the Covenant that the Prophet (Phuh) had installed at Medina. The charter of rights sets out a preamble for a rights doctrine as part of a legal and binding agreement based on Islamic structures. Its sets conditions on the legitimacy of power by validating a temporal power if it is succeeds in the strongest transforming his strength into a right, and obedience into a duty.

There seems on the surface that Islam is deemed as incompatible with the human rights principles by its liberal critics. There is no doubt that Islam as an eastern descendent of the Abrahamic faiths has suffered from its location in the Levant. This is despite the fact that it has been the main interlocutor of the doctrines of Greek and Roman jurists. The three main schools of jurisprudence in the Roman world were in Constantinople, Damascus and Tripoli. They had an influence on the development of Islamic theory when it succeeded in extending its empire over the entire Middle East and Turkey. ${ }^{56}$

However, the Islamic scripts have not been understood and its epistemological premise has become marred by colonial expansion and distortion. In Pakistan this has been felt by those who view the Hudood ordinances as derogation from a commitment to universal human rights principles. From their perspective the Pushtons in the embattled North West Frontier view the encroachment of the state as the danger to their ancient customs. This requires a further evaluation to determine if it is possible to place some substance to the Islamic concepts if they can be substantive changes that can alter the economic conditions of a society where the inhabitants live in dire poverty.

The writings of the jurist Michel Foucault reveal that he was admirer of a strand of Islam: "but one can find some general directions here: Islam values work; no one can be deprived of the fruits of his labour; what must belong to all (water, the subsoil) shall not be appropriated by anyone. With respect to liberties, they will be respected to the extent that their exercise will not harm others; minorities will be protected and free to live as they please on the condition that they do not injure the majority; between men and women there will not be inequality with respect to rights, but difference, since there is a natural difference. With respect to politics, decisions should be made by the majority, the leaders should be responsible to the people, and each person, as it is laid out in the Quran, should be able to stand up

${ }^{55}$ This finds a resonance in the compact of Medina. He states : The Prophet wrote a contract between the muhajirun ( refugees )and the ansar (domiciled) with which he concluded a covenant and a truce with the Jews, confirmed them in their religion and their property, and imposed obligations on them and guaranteed them certain rights

${ }^{56}$ This was the period of Justinian's empire when in the $5^{\text {th }}$ century with the Byzantine empire based at Constantinople the corpus juris of Roman laws was formulated 
and hold accountable he who governs. ${ }^{57}$

Foucault goes on to assert about the movement that he viewed unfolding from which he infers that he does "not feel comfortable speaking of Islamic government as an idea or even as an ideal. Rather, it impressed me as a form of political will. It impressed me in its effort to politicize structures that are inseparably social and religious in response to current problems. It also impressed me in its attempt to open a spiritual dimension in politics" ${ }^{58}$

In taking this logic further the application of Foucault's deduction from What is Critique ${ }^{59}$ is instructive. It implies that the legal system sets up "a social power structure where an objective adjudicator decides the outcomes" and that manifests in the judicial system. He argues that justice "is a bourgeois conception in its formulation of a hierarchy as reflected in the secular system and its product is the developed court system".

In his projection of a more acceptable justice he argues that there must be no institutionalizing of an unjust bourgeois concept of justice, which embodies the bigoted and corrupt laws that serve the rich and discriminate against the interests of the poor. This is the basis for the unpopularity of the Hudood ordinances in Pakistan. By taking this it needs a more popular expression of the enforcement of Sharia if it is to succeed in its application to the state. It cannot be done by simply co opting it as has been done in Pakistan to a hybrid legal system which has only served to cause friction in the framework and impeded the development of a coherent legal system.

\section{Conclusion}

In a comprehensive code such as Islam the temporal and spiritual power is fused unlike in Christianity and this makes it imperative that it must satisfy the requirement of fundamental rights. The Islamic countries that are presently facing public agitation have, so far, failed to implement a constitutional government. The Middle East has more than its share of dictators and still applies the outdated concept of divine authority in government where the Kings, Sheikhs and Emirs have near absolute power. These countries have no electoral mechanism nor have they implemented democratic or popular councils or tribunals to try the accused or elect their magistrates.

The example of Pakistan which, is a Middle Asian country that straddles both the Arab and the Asian countries, presents an instance of when the constitutional government that exists can be forged to portrayed to have achieved a secular identity and yet implements Sharia law. That it has so manifestly failed in drawing up a value system based on Islam is because it has not remained true to the Islamic ideals. It has not been able to fuse the principles of the religion and, at the same time, ensure a popular consensus in order to provide a judicial system where the jurisprudence is not despotic but uniform and merciful.

This structural defects has effected Pakistan and led to repeated periods of martial law with a government imposing emergency rules through legal framework orders which suspends the constitution or its abrogation. The

${ }^{57}$ First published in Le Nouvel Observateur, October 16-22, 1978.Excerpt from pages 203-9 of Foucault and the Iranian Revolution: Gender and the Seductions of Islamism by Janet Afary and Kevin B. Anderson, published by the University of Chicago Press. (C2005 by the University of Chicago

${ }^{58}$ Ibid.

${ }^{59}$ What is Critique?" in The Politics of Truth, eds. Sylvère Lotringer and Lysa Hochroth,. (New York: Semiotext(e), 1997 
political leaders lack real authority as there is no social compact based on a social contract. Further the absence of a social contract makes it impossible to secure a link to the preamble to the constitution thus it lacks legitimacy.

The Indonesian state which mirrors Pakistan in that it is a multi ethnic state with a largely Muslim population is pluralistic and has been dubbed as substantive in its application of Shariah. This is due to the inheritance of the civil code and civil procedure from the Dutch colonial jurisprudence. The five principles which provide the certainty are embedded in its constitution of the Indonesian people's identity in Article 29 which does not state Sharia as the supreme law of the land. There is still a small tier of the population effected by the religious codes, in the province of Aceh, where a form of implementation has been attempted it has been subject to critical scrutiny by the international human rights organizations.

There is a critical theory that has emerged which takes account of the fundamental tenets of Islam. This leads to the application of both the letter and the spirit of the Sharia laws. The exercise of political power is based on the interpretation of Quranic injunctions that are sacrosanct and this principle extends to the Hudood laws which form the criminal penalties in Islam. In dealing with the complex problem of legitimacy the logic of its application needs espousal because in the wrong hands they become the instruments of oppression. They can only be justified if they are in accordance with the popular consensus and are in accordance with a legal constitution that is the source of authority.

For there to be any future governance through the Islamic codes, such as that which enforces the corporal punishments set out in Hudood ordinances there has to be a general willingness that it should be observed. This is an important principle of the social contract derived from the abstraction which forms the basis for enacting laws. This basis is, according to Rousseau, an infallible agreement of the "Sovereign ruler" to protect and preserve the rule of law from its greatest danger which is the subversive effect of "natural law".

It will achieve a doctrine which separates the power of the executive, legislature and the judiciary which will lead to a transparent and accountable government. This will be a template that conforms with the religious rules that obey only 'legitimate powers' and not those imposed by the preponderance of a superior power which is not rights based. The people must be franchised through elections and due process must be mandatory.

The critical theory of secularism and Sharia is relevant as it challenges absolutism and allows for sovereign power through popular vote, which has to be integrated into a whole juridical -political system to derive legitimacy. This concept is inherent in Islam as there is no notion of a priesthood that acts as an interlocutor between the divine authority and the people. This new framework where the laws are synthesized in order to produce a constitutional doctrine that enacts laws which conform to the spirit of the original framers of the first Muslim Constitution, where the rights of all sections of the community were upheld. 


\section{Bibliography}

Abdal-Haqq, Irshad. "Understanding Islamic Law : From Classical to Contemporary." In Islamic Law : An Overview of its Origins an Elements, by Amineh Beverly McCloud, 4. Altra Mira Press, 2006.

Afary, Janet, and Kevin B. Anderson. Foucault ad the Iranian Revolution : Gender and the Seductions of Islamism. Chicago: University of Chicago Press, 2005.

Dien, Mawil Izzi. "Islamic Law : From Historical Foundations to Contemporary Practice." n.d.: 69.

Endress, Gerhard. Islam : An Introdouction to Islam. Columbia University Press, 1988.

Hosen, Nadirsyah. "Religion and the Indonesian Constitution : A recent debate." Journal of South Asian Studies, 2005: 419-440.

Ibn Rushd-The Great Muslim Philosopher Who Planted Seeds of European Renaissance. n.d. http://www.aljadid.com/classics/0422.sallomn.html.

"Islamic Human Rights Declaration of Cairo." Ninetennth Islamic Conference. Cairo: Foreign Ministers, 1990.

Juwana, H., Y. Barkinti, and Y. K. Dewi. "The Development of Islamic Financial Law." Winconsin International Law Journal, 2008: 774-794.

Khan, MA Muqtedar. The Compact of Medina : A Constitutional Theory of the Islamic State. Mirror International, 2001.

Makdisi, George. The Rise of Colleges : Institutions of Learning in the Islam and West. Edinburgh : Edinburgh University Press, 1981.

Nasr, Vali. The Shia Revival. New York: W.W. Norton, 2006.

Ramadan, Tariq. tariqramadan. March 2005. http://www.tariqramadan/ article264.

Rousseau, J.J. Social Contract. Dent Publishing Company, 1923.

Sardar, Ziauddin. "Science in Islamic." In Routlege Encyclopedia of Philosophy, 02-02. 2008. 